\title{
ACCELERATOR-MEASURED ${ }^{14} \mathrm{C}$ ACTIVITY IN TREE RINGS FROM THE VICINITY OF THE FIRST ATOMIC BOMB TEST
}

\author{
$S$ W LEAVITT \\ Department of Geology, University of Wisconsin-Parkside \\ Kenosha, Wisconsin 53141-2000 \\ and \\ AUSTIN LONG \\ Department of Geosciences, University of Arizona, Tucson, Arizona 85721
}

\begin{abstract}
Detonation of the first fission bomb at White Sands, New Mexico, on July 16, 1945 , produced a tremendous neutron flux capable of creating tritium and radiocarbon byproducts. We sampled a 115-year-old pinyon (Pinus edulis) $10 \mathrm{~km}$ east of the Trinity test site to determine ${ }^{14} \mathrm{C}$ evidence of this event. The most likely mechanism for this enrichment in the 1945 tree ring would be fixation of ${ }^{14} \mathrm{CO}_{2}$ produced at the blast site and carried with the fallout cloud over the pinyon site. Analysis of cellulose of the 1944 and 1945 rings shows $\delta^{13} \mathrm{C}$ values of -19.9 and $-19.5 \%$, respectively, and ${ }^{14} \mathrm{C}$ activity (fraction of modern uncorrected for $\delta^{13} \mathrm{C}$ ) as $0.991 \pm .005$ and $0.991 \pm .006$, respectively. It is likely that the duration and/or concentration of the ${ }^{14} \mathrm{CO}_{2}$ exposure was not sufficient to increase ${ }^{14} \mathrm{C}$ activity expected for that year.
\end{abstract}

\section{INTRODUCTION}

On the morning of July 16, 1945, at 5:29:45 AM, the first fission bomb (plutonium) was detonated at Trinity site in the White Sands Proving Grounds area $250 \mathrm{~km}$ south of Los Alamos. The energy released from this bomb was the equivalent of 18.6 kilotons of TNT and the explosion was accompanied by the release of nuclear radiation in the form of beta (and some alpha) particles, neutrons and gamma rays. Ninety-nine percent of the neutron flux emitted within the first $10^{-2}$ seconds of detonation, dominated by fast neutrons (Glasstone, 1964). Within the first second, elastic and inelastic collisions with nuclei and subsequent transfer of kinetic energy resulted in neutrons with a wide range of speeds including slow (thermal) neutrons. Away from the origin, interaction with light nuclei of air molecules additionally slowed fast neutrons, and the thermal neutrons so produced were susceptible to capture by hydrogen and nitrogen atoms to produce tritium and ${ }^{14} \mathrm{C}$, respectively.

We sampled a pinyon (Pinus edulis) tree in the vicinity of the Trinity site to determine if the 1945 growth ring had acquired an elevated ${ }^{14} \mathrm{C}$ activity as a consequence of this event. We report our findings on ${ }^{13} \mathrm{C} /{ }^{12} \mathrm{C}$ ratios and ${ }^{14} \mathrm{C}$ activity of wood from this tree, and consider the mechanisms which could produce enrichment in the tree rings.

\section{METHODS}

With clearance from the White Sands Missile Range and an escort by US Army personnel, a field party consisting of ourselves and representatives of the Laboratory of Tree-Ring Research at the University of Arizona drove into the Sierra Oscura Mts on September 17, 1982, to find a suitable tree for sampling. A tree was located at an elevation of $2475 \mathrm{~m}$ ca $3.2 \mathrm{~km}$ 
north of Oscura Peak and ca $9.7 \mathrm{~km}$ east of Ground Zero (elev $1510 \mathrm{~m}$ ). The straight-line path from the tree to Ground Zero was unobstructed by vegetation or rocks.

The tree was cut with a chain saw to obtain a cross-section. After sanding, the cross-section was dated by the Modern Studies Group at the Laboratory of Tree-Ring Research; the inside age was 1866 . Individual rings from 1941-1954 were separated along one radius, and cellulose was isolated after the method of Green (1963). Cellulose was combusted to $\mathrm{CO}_{2}$ in a microcombustion system and analyzed mass-spectrometrically to determine $\delta^{13} \mathrm{C}$ of each of the rings. $\mathrm{CO}_{2}$ from two rings, 1944 and 1945, was converted to graphite by the catalytic reduction method of Jull et al (1986) and ${ }^{14} \mathrm{C}$ activity with respect to modern was determined by tandem accelerator mass-spectrometry. Although a $\delta^{13} \mathrm{C}$ correction was not made, the ${ }^{14} \mathrm{C}$ activities can be directly compared because the $\delta^{13} \mathrm{C}$ values are nearly identical.

\section{MECHANISM FOR ENRICHMENT}

Three mechanisms might enrich ${ }^{14} \mathrm{C}$ activity of the pinyon tree: 1$)$ in situ neutron irradiation from the initial blast, 2) in situ irradiation from fallout byproducts and 3) plant fixation of blast-produced ${ }^{14} \mathrm{CO}_{2}$ out of the fallout cloud which fumigated the site.

The first mechanism is a consequence of the tremendous neutron flux produced at detonation. An equation for integrated (all energies) neutron flux $\left(\mathrm{N}_{\mathrm{t}}\right.$ in neutrons $\left./ \mathrm{cm}^{2}\right)$ is given by Glasstone (1964) as follows

$$
\mathrm{N}_{\mathrm{t}}=\frac{8.6 \times 10^{18} \mathrm{~W}}{\mathrm{D}^{2}} \mathrm{e}^{-\mathrm{D} / 210}
$$

where $\mathrm{D}$ is the distance from the blast in yards and $\mathrm{W}$ is the nuclear yield in kilotons TNT equivalent. At $457 \mathrm{~m}$, the closest distance for which the relationship is valid, the neutron flux of the Trinity bomb (18.6 kT yield) was $5.9 \times 10^{13}$ neutrons $/ \mathrm{cm}^{2}$. However, at a distance of $9.7 \mathrm{~km}$, the integrated flux was ca $10^{-10} \mathrm{n} / \mathrm{cm}^{2}$. Thus, in situ production of ${ }^{14} \mathrm{C}$ by this initial neutron flux is highly unlikely.

The fallout products emitted much energy, primarily as beta particles and gamma radiation (Glasstone, 1964). The fallout cloud did drift northeastward from Ground Zero at ca $16 \mathrm{~km} \mathrm{~h}^{-1}$, and the arrival of a radioactive peak detected by Geiger counters at 4:20 PM (and lasting $1 \mathrm{hr}$ ) at the town of Carrizozo (Lamont, 1965) suggests an eastward component of ca $8 \mathrm{~km} \mathrm{~h}^{-1}$. However, prospects for gamma rays released from fission products to be sufficiently energetic to free thermal neutrons from atomic nuclei, which could then be captured by ${ }^{14} \mathrm{~N}$, would be negligible. Neutron flux from fission of any heavy atoms remaining in the fallout would also be inconsequential.

The arrival of fallout, however, should have carried with it high concentrations of ${ }^{14} \mathrm{CO}_{2}$ produced by $(n, p)$ reactions from the initial neutron flux at Ground Zero interacting with atmospheric ${ }^{14} \mathrm{~N}$. The total flux of neutrons onto a hemispheric area with a radius of $457 \mathrm{~m}$ would be $5.9 \times$ 
$10^{13} \mathrm{n} / \mathrm{cm}^{2} \times 1.3 \times 10^{10} \mathrm{~cm}^{2}=7.7 \times 10^{23}$ neutrons. If a substantial portion of these are thermal neutrons, with nitrogen comprising $78 \%$ of the atmosphere by volume with a neutron cross-section ca $5 \mathrm{x}$ that of hydrogen, most of these neutrons could be captured by ${ }^{14} \mathrm{~N}$. If we assume that this capture results in ca 1 mole of ${ }^{14} \mathrm{C}$ produced in a hemispheric volume with a radius of $1829 \mathrm{~m}$, this would be ca $10,000 \mathrm{x}$ the natural ${ }^{14} \mathrm{C}$ content of such a volume. Even allowing for some dispersion and, possibly, a smaller fraction of the flux as thermal neutrons, as suggested in the study of ${ }^{36} \mathrm{Cl}$ production from the Hiroshima bomb (Haberstock et al, 1986), the ${ }^{14} \mathrm{C}$ activity of the fallout cloud could still be quite high as it fumigated the pinyon.

\section{RESULTS}

Figure 1 contains the $\delta^{13} \mathrm{C}$ and ${ }^{14} \mathrm{C}$ results for cellulose from the pinyon. The $\delta^{13} \mathrm{C}$ values show an increasing trend from 1941 to 1954 , but the ${ }^{14} \mathrm{C}$ activity of the 1944 and 1945 rings are virtually indistinguishable. A summary of ${ }^{14} \mathrm{C}$ activity $\left(\triangle^{14} \mathrm{C}\right)$ of 1944 and 1945 tree rings from other locations around the world by Fan et al (1986) indicates, even in trees from distant areas with background atmospheric ${ }^{14} \mathrm{C}$, the ${ }^{14} \mathrm{C}$ activity of the 1944 and 1945 rings are approximately the same $(0.991$ fraction modern $\approx-9 \%$ $\triangle{ }^{14} \mathrm{C}$ ). Thus, the ${ }^{14} \mathrm{C}$ similarity of the White Sands 1944 and 1945 rings indicates there is no real ${ }^{14} \mathrm{C}$ enrichment in the 1945 ring. The number of extra ${ }^{14} \mathrm{C}$ atoms fixed by the tree during the fallout cloud fumigation of ca 1-hr duration was sufficiently small to be diluted by the background carbon fixed over the other $1000^{+} \mathrm{hr}$ of the growing season. It might be possible to subdivide the 1945 ring and locate cells that have a high ${ }^{14} \mathrm{C}$ activity, but our whole-ring analysis shows the exposure was too short and/or ${ }^{14} \mathrm{C}$ activity of the $\mathrm{CO}_{2}$ was not sufficiently high to bias the ring ${ }^{14} \mathrm{C}$ activity.

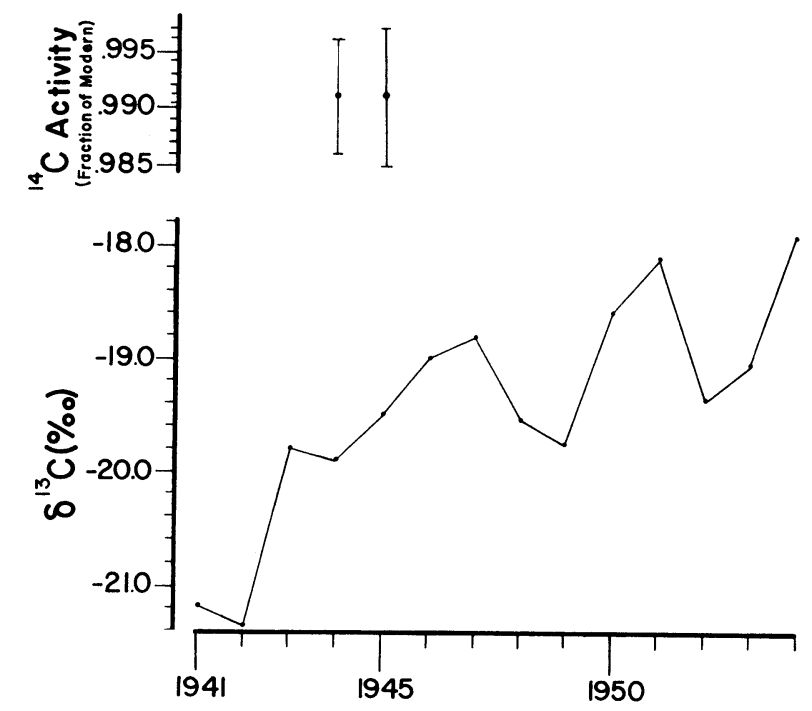

Fig 1 . The $\delta^{13} \mathrm{C}$ results from cellulose of the $1941-1954$ tree rings, and ${ }^{14} \mathrm{C}$ activity (without $\delta^{13} \mathrm{C}$ correction) of cellulose from the 1945 and 1946 tree rings of the White Sands Oscura Mts pinyon pine 


\section{ACKNOWLEDGMENTS}

We thank T Stipe, J Kilcrease, V E Ebert and J R Lovelady of the US Army White Sands Missile Range for providing access to the site. T Swetnam and E Kennedy-Sutherland of the Laboratory of Tree-Ring Research accompanied us and helped select the tree. We are extremely grateful to D J Donahue, L J Toolin, A J T Jull and T W Linick of the University of Arizona Tandem Accelerator Laboratory for ${ }^{14} \mathrm{C}$ analysis.

\section{REFERENCES}

Fan, CY, Chen, TM, Yun, SX and Dai, KM, 1986, Radiocarbon activity variation in dated tree rings grown in MacKenzie Delta, in Stuiver, $M$ and $\mathrm{Kra}$, RS, eds, Internatl ${ }^{14} \mathrm{C}$ conf, 12 th, Proc: Radiocarbon, v 28, no. 2A, p 300-305.

Glasstone, S, ed, 1964, The effects of nuclear weapons: Washington, DC, US Atomic Energy Comm.

Green, JW, 1963, Wood cellulose, in Whistler, RL, ed, Methods of carbohydrate chemistry: New York, Academic Press, p 9-21.

Haberstock, G, Heinzl, J, Korschinek, G, Morinaga, H, Nolte, E, Ratzinger, U, Kato, K and Wolf, M, 1986, Accelerator mass spectrometry with fully stripped ${ }^{36} \mathrm{Cl}$ ions, in Stuiver, $\mathrm{M}$ and Kra, RS, eds, Internatl ${ }^{14} \mathrm{C}$ conf, 12 th, Proc: Radiocarbon, v 28, no. 2A, p 204-210.

Jull, AJT, Donahue, DJ, Hatheway, AL, Linick, TW and Toolin, LJ, 1986, Production of graphite targets by deposition from $\mathrm{CO} / \mathrm{H}_{2}$ for precision accelerator ${ }^{14} \mathrm{C}$ measurements, in Stuiver, $\mathrm{M}$ and Kra, RS, eds, Internatl ${ }^{14} \mathrm{C}$ conf, 12th, Proc: Radiocarbon, v 28, no. $2 \mathrm{~A}$, p 191-197.

Lamont, L, 1965, Dawn over zero, the story of the atomic bomb: New York, Atheneum. 